\title{
Silicate Rock-Based Fertilizers Improved the Production of Sugarcane Grown on Udipsamments Kediri, East Java, Indonesia
}

\author{
Joko Priyono ${ }^{1, ~ *}$, Djajadi ${ }^{2}$, Sulis Nur Hidayati ${ }^{2}$, Sandi Gunawan $^{3}$, Ikhlas Suhada ${ }^{4}$ \\ ${ }^{1}$ Department of Soil Science, University of Mataram, Mataram, Indonesia \\ ${ }^{2}$ Indonesian Sweetener and Tuber Crops Research Institute, Malang, Indonesia \\ ${ }^{3}$ Sugarcane Research Center of PT Perkebunan Nusantara (PTPN) X, Kediri, Indonesia \\ ${ }^{4}$ PT. JIA Agro Indonesia, West Lombok, Indonesia
}

Email address:

joko_priyono@unram.ac.id (J. Priyono), jaydjajadi61@gmail.com (Djajadi), sulisnh@yahoo.con (S. N. Hidayati), gunawan19@gmail.com (S. Gunawan), suhadaku32@gmail.com (I. Suhada)

${ }^{*}$ Corresponding author

\section{To cite this article:}

Joko Priyono, Djajadi, Sulis Nur Hidayati, Sandi Gunawan, Ikhlas Suhada. Silicate Rock-Based Fertilizers Improved the Production of Sugarcane Grown on Udipsamments Kediri, East Java, Indonesia. International Journal of Applied Agricultural Sciences.

Vol. 6, No. 2, 2020, pp. 16-20. doi: 10.11648/j.ijaas.20200602.11

Received: April 12, 2020; Accepted: April 27, 2020; Published: May 15, 2020

\begin{abstract}
Improving the farming productivity and profitability of sugarcane in Indonesia requires an appropriate fertilization method. So, three types of silicate rock-based fertilizers were developed and tested in field condition. The main objectives of this research were to identify the effects of liquid-silicate rock fertilizer (LSRF) in addition to NPK, and granules of $\mathrm{NP}_{70}-\mathrm{Si}$ and $\mathrm{NP}_{100}$ - $\mathrm{Si}$ on the growth and yield components of sugarcane grown on Udipsamments. A randomized complete block design was employed with the treatment consisting of F-0 (NPK) as the reference of fertilizer package, F-1 (NPK + LSRF applied onto the leaf), F-2 (NPK + LSRF applied to the soil), F-3 ( $\left.\mathrm{NP}_{70}-\mathrm{Si}\right)$, and F-4 $\left(\mathrm{NP}_{100}-\mathrm{Si}\right)$, and those were replicated in five blocks. Results reveal that the applications of those different fertilizer packages significantly affected the germination of seed buds, cane production, and sugar yield, but did not for the other growth and yield components. The order of its agronomic and economic effectiveness of the fertilizer packages, based on the value of either cane production or sugar yield, was F-2 $>$ F-1 $>$ F- $4>$ F- $0>$ F-3. Therefore, the use of the fertilizer package of F-2 (NPK + LSRF) may be promoted as an appropriate fertilization method to improve the farming productivity and profitability of sugarcane in Indonesia.
\end{abstract}

Keywords: Cane Production, Silicate Rock, Sugarcane, Si Fertilizer, Sugar Yield

\section{Introduction}

Sugarcane (Saccharum officinarum) is an important cash crop in Indonesia. During the last decade, the status of Indonesia has switched from an exporting to importing country for sugar. The situation is not only caused by the increase in national demand, but also by the decline of domestic production of sugar. A substantial effort to reach sustainable self-supporting for sugar is by implementing the specific recommendation of the application of multi-nutrient and organic fertilizers [1]. However, particular attention should also be given to the use of silicate ( $\mathrm{Si}$ ) - a commonly neglected nutrient but so much beneficial for sugarcane production.

In the farming of sugarcane, the use of $\mathrm{N}, \mathrm{P}$, and $\mathrm{K}$, or NPK fertilizers is essential because the plant requires a large amount of those nutrients. Nevertheless, continuous application of those nutrients at high rates in the successive-monoculture farming system can deplete the other essential nutrients [2]. Moreover, sugarcane is a silicate-accumulator plant [2], absorbing much more $\mathrm{Si}$ than N, P, or K [3-5]. Many researchers reported that the application of Si fertilizers improves cane production [6-8]. The use of Si fertilizers may also suppress pest and disease attacks [9-12] and the harmful effects of saline soils on 
plant growth [13-15]. Based on those references, the use of Si-based fertilizers containing all plant-essential nutrients may be proposed as an essential part of the exertions for improving the production of sugarcane in Indonesia. The question is, which kind of fertilizer package is suitable especially for the smallholder farmers of sugarcane.

The farming business of sugarcane in Indonesia is mostly (54\%) operated by smallholder farmers, and partly by the state $(16 \%)$ and private $(30 \%)$ companies [16]. But, not many of the smallholders invest the Si-based fertilizers in sugarcane farms. Besides the lack of their knowledge, the foremost cause of the case is the high cost of available $\mathrm{Si}$ fertilizers. Thus, the use of cheap but effective Si-based fertilizers could be the best solution, and the innovation of producing Si-fertilizers based on local resources should become a vital part of the development program of sugarcane in Indonesia.

During the last several decades, there has been an increasing interest of agronomists worldwide, including in Indonesia, to the utilization of Si-containing materials for use as a multi-nutrient fertilizer. Those include ground silicate rocks [17], calcium silicate slag [18-21, 4], boiler ash, furnace slag, and zeolite [8], and steel slag [22] as the sources for Si-containing fertilizer. However, the solubility of Si from those materials is commonly very low. Consequently, the application of those materials requires a very high rate ( $>$ 20 t.ha').

A promising effective fertilizer made from basaltic-silicate rocks is liquid-silicate rock fertilizer (LSRF) [23]. The results of a field test [24] show that the foliar application of LSRF, in addition to the basal fertilizers of $\mathrm{N}, \mathrm{P}$, and $\mathrm{K}$, on sugarcane doubled the cane production reaching 184 t.ha, and increased sugar rendement and yield respectively reaching $8.4 \%$ and 15.4 t.ha. However, sugarcane is a high and dense-growing plant, so that the foliar application of
LSRF requires a particular tool and high cost. For this reason, we have developed the other silicate rock-based fertilizers in granule form, i.e., $\mathrm{NP}_{70}-\mathrm{Si}$ and $\mathrm{NP}_{100}-\mathrm{Si}$. The effectiveness of those fertilizers for sugarcane was evaluated in this present research.

The primary objective of this research was to assess the agronomic and economic effectiveness of the newly developed Si fertilizers, i.e., LSRF, $\mathrm{NP}_{70}-\mathrm{Si}$, and $\mathrm{NP}_{100}-\mathrm{Si}$, to improve sugarcane production.

\section{Materials and Method}

\subsection{Site Description}

This research was carried out in the research station of the state company of PTPN X in Kediri, East Java, Indonesia ( $\left.7^{\circ} 52^{\prime} 34.1^{\prime \prime S} 112^{\circ} 10^{\prime} 11.1^{\prime \prime E}\right)$ for 12 months (April 2017 to May 2018). The land consisted of fairly deep $(30-40 \mathrm{~cm})$ sandy textured soil (Udipsamments), being characterized by slightly acid $(\mathrm{pH} 5.4)$, high $\mathrm{N}$ total $(0.13 \%)$ and Bray-extractable P ( $\left.87 \mathrm{mg} \cdot \mathrm{kg}^{-}\right)$, low cation exchange capacity $\left(6.1 \mathrm{cmol} . \mathrm{kg}^{-}\right)$, and fair to slightly high exchangeable $\mathrm{Na}^{+}, \mathrm{K}^{+}$, $\mathrm{Ca}^{+2}$, and $\mathrm{Mg}^{+2}$, which were, respectively, 1.0, 0.98, 3.3, and $0.8 \mathrm{cmol} . \mathrm{kg}^{-}$.

\subsection{Experimental Design}

This experiment was laid out in a randomized complete block design with five replications (blocks), and the treatments were five fertilizer packages described in Table 1. The planted cane seedling was PS 881 variety. The cane seeding was cut for use as the seed in which each cut contained three seed buds. Each experimental plot consisted of 10 rows of $16-\mathrm{m}$ length, and the distance between rows was $1.35 \mathrm{~m}$. The seedling canes containing 48 buds were planted in each row; thus, there were 480 buds per plot of $216 \mathrm{~m}^{2}$.

Table 1. The description of fertilizer packages (treatments) used in this current experiment.

\begin{tabular}{|c|c|c|}
\hline $\begin{array}{l}\text { Treatment } \\
\text { Code }\end{array}$ & Description & Application Method \\
\hline $\mathrm{F}-0$ & $\begin{array}{l}\text { Reference fertilizer }\left(\mathrm{NPK}^{*}\right): 160 \mathrm{~N}+72 \mathrm{P}_{2} \mathrm{O}_{5}+150 \mathrm{~K}_{2} \mathrm{O} \\
\text { kg.ha }\end{array}$ & Applied twice at 7 and 30 days after planting (d.a.p) through the soil at 5-cm depth. \\
\hline $\mathrm{F}-1$ & F-0 + 24-L LSRF (NPK + LSRF) & LSRF was applied onto the leaf and stem 4 times at 21, 35, 50, and 77 d.a.p. \\
\hline $\mathrm{F}-2$ & F-0 + 24-L LSRF (NPK + LSRF) & LSRF was applied twice through the soil at 7 and 30 d.a.p. \\
\hline F-4. & $\mathrm{NP}_{70}-\mathrm{Si}$ (a granule fertilizer), $800 \mathrm{~kg} \cdot \mathrm{ha}^{-}$. & $\mathrm{NP}_{70}$-Si was applied twice through the soil, $2 \times 50 \%$ of the rate, at 7 and 30 d.a.p. \\
\hline F-5. & $\mathrm{NP}_{100}-\mathrm{Si}$ (a granule fertilizer) 800 kg.ha ${ }^{-}$ & $\mathrm{NP}_{100}$-Si was applied twice through the soil, $2 \times 50 \%$ of the rate, at 7 and 30 d.a.p. \\
\hline
\end{tabular}

* NPK in this research was a combination of $160 \mathrm{~N}+72 \mathrm{P}_{2} \mathrm{O}_{5}+150 \mathrm{~K}_{2} \mathrm{O}$ (kg.ha), respectively, in forms of urea, TSP, and KCl.

\subsection{Data Collection and Analysis}

The main observed parameters were the growth and yield components. The growth components were (1) germination rate of seed buds observed at one month after planting (m.a.p), (2) plant height (cane length) of 3, 6, and 9 m.a.p, (3) cane diameter of 6 and 9 m.a.p., and (4) plant population of 3, 6, and 9 m.a.p. The observed yield components were (1) cane production harvested at 12 m.a.p, (2) brix (the sweetness or the percentage of sugar relative to the cane juice), (3) rendement (the percentage of sucrose in the cane), and (4) sugar yield.
Data of each observed parameter were subjected to the analysis of variant (ANOVA), followed by the analysis of least significant difference (LSD) at $\alpha=0.05$ for the parameters that were significantly affected by the treatments. The relative effectiveness of each fertilizer package was calculated as the percentage of cane production (for agronomic effectiveness) and of farming benefit (for economic effectiveness) over that for the reference fertilizer package (F-0). 


\section{Results and Discussion}

\subsection{Growth Components}

The effect of different fertilizer packages (as shown in Table 1) on the growth components of sugarcane is summarized in Table 2. The treatments did not significantly affect the growth components but the percentage of germinating seed buds. The germination of seed buds receiving $\mathrm{NP}_{100}$-Si was about $6 \%$ higher than for that of NPK (the reference fertilizer).

As shown in Table 2, the percentages of germinating seed buds receiving the treatments of F- $0, \mathrm{~F}-1$, and F-2 were nearly the same (about 45.6\%); whereas for F-3 and F-4 were 47.2 $49.6 \%$, or $3-4 \%$ higher than for that of the reference $(\mathrm{F}-0)$. However, the plant population of 3,6, and 9 months was not significantly affected by the application of different fertilizer packages. The plant population of the 3 months ranged from about 123 to $135 \times 10^{3}$ ha', whereas for that of 6 and 9 months were about the same $\left(62 \times 10^{3} \mathrm{ha}^{-}\right)$. The diameter of cane reached the maximum value (about $31 \mathrm{~mm}$ ) after the plant was six-month-old, and that was not affected by the treatments. Similarly, the cane length (plant high) was not affected by the treatments, reaching a maximum extent of about $115-118 \mathrm{~cm}$ after 6-month old.

Based on the results of simple linear correlation analyses, there was no close correlation or cause-effect relationship between the germinating rates of seedling cane with plant population, height, or cane diameter. It seems that a sufficient supply of the macronutrients of N, P, and K from all fertilizer packages for sugarcane provides no difference in the growth components.

\subsection{Yield Components}

The effect of different fertilizer packages on the yield components of sugarcane is summarized in Table 3. The yield components significantly affected by the treatments were only the cane production and sugar yield.

As shown in Table 3, the application of LSRF (in addition to NPK) applied on the leaf (F-1) or through the soil (F-2) provided the cane production for about 105 t.ha or $6 \%$ higher than for that of the reference F-0 (NPK) which was about 99 t.ha'. Meanwhile, the application of the granulated silicate rock fertilizers $\left(\mathrm{NP}_{70}-\mathrm{Si}\right.$ and $\left.\mathrm{NP}_{100}-\mathrm{Si}\right)$ produced, respectively, 93 and 103 t.ha, and those productions were not significantly different from that of the reference F-0. The trend of sugar yield in response to the treatments was similar to that of cane production. In contrast, the percentages of sugar brix dan rendement were not affected by the use of different fertilizer packages, which respectively were about 18 and $7.7 \%$.

Table 2. The effects of fertilizer packages on the growth components of sugarcane.

\begin{tabular}{|c|c|c|c|c|c|c|c|}
\hline \multirow{2}{*}{ Parameter } & \multirow{2}{*}{ Unit } & \multicolumn{5}{|c|}{ Fertilizer Packages } & \multirow{2}{*}{$\operatorname{LSD}_{\alpha=0.05}$} \\
\hline & & F-0 & F-1 & F-2 & F-3 & F-4 & \\
\hline Seed Germination & $\%$ & 45.6 a & $45.9 \mathrm{a}$ & $45.6 \mathrm{a}$ & $47.2 \mathrm{ab}$ & $48.6 \mathrm{~b}$ & 1.8 \\
\hline \multicolumn{8}{|l|}{ Plant Population: } \\
\hline 3 months & $10^{3} \cdot \mathrm{ha}^{-}$ & 135.3 & 131.4 & 123.5 & 125.2 & 126.4 & - \\
\hline 6 months & $10^{3} \cdot \mathrm{ha}^{-}$ & 64.7 & 62.1 & 62.6 & 61.7 & 62.0 & - \\
\hline 9 months & $10^{3} \cdot \mathrm{ha}^{-}$ & 67.5 & 65.3 & 63.3 & 65.5 & 64.0 & - \\
\hline \multicolumn{8}{|l|}{ Cane Diameter: } \\
\hline 6 months & $\mathrm{mm}$ & 30.2 & 31.1 & 30.9 & 31.1 & 31.2 & - \\
\hline 9 months & $\mathrm{mm}$ & 30.3 & 31.3 & 31.6 & 31.2 & 31.3 & - \\
\hline \multicolumn{8}{|l|}{ Plant Height: } \\
\hline 6 months & $\mathrm{cm}$ & 115.4 & 115.5 & 118.0 & 115.6 & 118.0 & - \\
\hline 9 months & $\mathrm{cm}$ & 269.1 & 275.2 & 261.9 & 270.9 & 274.3 & - \\
\hline
\end{tabular}

The values in the same row, labeled with the same letter, are not significantly different based on its $\operatorname{LSD}_{\alpha=0.05}$.

Table 3. The effects of fertilizer package on the yield components of sugarcane.

\begin{tabular}{|c|c|c|c|c|c|c|c|}
\hline \multirow{2}{*}{ Parameter } & \multirow{2}{*}{ Unit } & \multicolumn{5}{|c|}{ Fertilizer Packages } & \multirow{2}{*}{$\operatorname{LSD}_{\alpha=0.05}$} \\
\hline & & F-0 & F-1 & F-2 & F-3 & F-4 & \\
\hline Cane production & t.ha ${ }^{-}$ & $98.9 \mathrm{~b}$ & $104.6 \mathrm{c}$ & $105.2 \mathrm{c}$ & $92.5 \mathrm{a}$ & $102.5 \mathrm{bc}$ & 6.7 \\
\hline RAE-cane production & $\%$ & 100.0 & 105.8 & 106.4 & 93.5 & 103.6 & - \\
\hline Sugar yield & t.ha ${ }^{-}$ & $7.7 \mathrm{~b}$ & $7.9 \mathrm{bc}$ & $8.1 \mathrm{c}$ & $7.0 \mathrm{a}$ & $7.9 \mathrm{bc}$ & 0.5 \\
\hline RAE-sugar yield & $(\%)$ & 100.0 & 102.6 & 105.2 & 90.9 & 102.4 & - \\
\hline Brix & $(\%)$ & 8.0 & 17.9 & 17.8 & 18.6 & 18.3 & - \\
\hline Rendement & $(\%)$ & 7.8 & 7.6 & 7.7 & 7.5 & 7.7 & - \\
\hline
\end{tabular}

The values in the same row, labeled with the same letter, are not significantly different based on its $\operatorname{LSD}_{\alpha=0.05}$. $\mathrm{RAE}=$ relative agronomic effectiveness.

Table 4. Summary of economic analysis of sugarcane farming

\begin{tabular}{lllll}
\hline \multirow{2}{*}{ Components } & Fertilizer Packages & & & \\
\cline { 2 - 5 } & F-0 & F-1 & F-2 & F-3 \\
\hline Materials $\left(\mathrm{M}_{\mathrm{IDR}}\right)$ & 23.65 & 25.57 & 25.57 & 24.75 \\
Operational $\left(\mathrm{M}_{\mathrm{IDR}}\right)$ & 6.00 & 6.70 & 6.00 & 6.00 \\
Total cost $\left(\mathrm{M}_{\mathrm{IDR}}\right)$ & 29.650 & 32.270 & 31.570 & 3.00 \\
\hline
\end{tabular}




\begin{tabular}{|c|c|c|c|c|c|}
\hline \multirow{2}{*}{ Components } & \multicolumn{5}{|c|}{ Fertilizer Packages } \\
\hline & F-0 & F-1 & F-2 & F-3 & F-4 \\
\hline Product (t.ha) & 98.93 & 104.58 & 105.21 & 92.47 & 102.05 \\
\hline Rendement (\%) & 7.8 & 7.6 & 7.7 & 7.5 & 7.7 \\
\hline Prod. Price $\left(\mathrm{M}_{\mathrm{IDR}} \cdot \mathrm{t}^{-}\right)$ & 0.65 & 0.65 & 0.65 & 0.65 & 0.65 \\
\hline Prod. value $\left(\mathrm{M}_{\mathrm{IDR}}\right)$ & 64.304 & 67.978 & 68.388 & 60.105 & 66.331 \\
\hline Benefit (MIDR.ha־.'”) & 34.654 & 35.708 & 36.818 & 29.355 & 35.581 \\
\hline REE - benefit (\%) & 100.0 & 103.0 & 106.2 & 84.7 & 102.7 \\
\hline
\end{tabular}

$\mathrm{M}_{\mathrm{IDR}}=$ millions of Indonesian dollar (Rupiah), $1 \mathrm{US} \$ 14.500 \mathrm{IDR}$.

\subsection{Effectiveness of Silicate Rock-Based Fertilizers}

The effectiveness of the silicate-rock based fertilizers relative to the reference fertilizer package, based on agronomic (RAE) and economic (REE) parameters, respectively, are shown in Tables 3 and 4. The trends of RAE and REE are similar, F-2 $>$ F-1 $>$ F-4 $>$ F-0 $>$ F3. Based on those evaluations, the most effective fertilizer package for sugarcane is F-2 (NPK + LSRF applied through the soil). Adding LSRF to the basalt fertilizer (NPK) improved about $6 \%$ of sugarcane production or cash benefit of the farming. Thus, NPK + LSRF may be promoted as an appropriate fertilizer package to improve productivity as well as the profitability of the farming of sugarcane.

The result of earlier research [24], applying a high rate of LSRF to sugarcane grown on the well-irrigated land with loamy textured soil, produced cane of about 184 t.ha ${ }^{-}$and the cane length was about $3.8 \mathrm{~m}$. Compared to the cane production gained in this present research, the results of [24] was much higher. Meaning that there is a chance to improve cane production higher than 105 t.ha', which may be by increasing the application rate of NPK + LSRF. Thus, further research is required to be able to reach higher or maximum sugar production; and it may be focused on defining the optimum fertilizer type and application, plant variety, or/and water supply.

\section{Conclusion}

The application of 5 different fertilizer packages, which were (NPK), (NPK+ LSRF applied on plant leaf), (NPK + LSRF applied through the soil), $\mathrm{NP}_{75}-\mathrm{Si}$, and $\mathrm{NP}_{100}-\mathrm{Si}$, significantly affected the production of cane and sugar but did not for the other growth and yield components of sugarcane grown on Udipsamments. Based on either its agronomic or economic effectiveness, the application of $\mathrm{NPK}+\mathrm{LSRF}$ is the best fertilization method in this research. Therefore, the use of $160-\mathrm{kg} \mathrm{N}+72-\mathrm{kg} \mathrm{P}_{2} \mathrm{O}_{5}+150-\mathrm{kg} \mathrm{K}_{2} \mathrm{O}+$ 25-L LSRF per ha may be proposed as an appropriate method to improve sugarcane production, especially in Indonesia. Indeed, further researches associating to the identification of the optimum rate of fertilizer application for different plant varieties and watering strategy are required to obtain higher production of sugarcane.

\section{Acknowledgements}

We acknowledge the Directorate General of Research and Technology, Ministry of Research, Technology and Higher
Education, The Republic of Indonesia, for its financial support to this research. Also, we thank Balitas-Malang, LPPM-University of Mataram, PTPN X, and PT. JIA Agro Indonesia for their supports to this research.

\section{References}

[1] Kementan RI. (2015). Permentan No: 19/Permentan/HK. 140/4/2015 tentang rencana strategis Kementerian Pertanian tahun 2015-2019.

[2] Epstein, E. (1999). Silicon. Ann. Rev. Plant Physiol., Plant Mol. Biol., 50: 641-664.

[3] Samuels, G. (1969). Silicon and sugar. Sugar y Azucar, 65: 2529.

[4] Anderson, D. L., Snyder, G. H. and Martin, F. G. (1991). Multi-year response of sugarcane to calcium silicate slag on everglades histosols. Agronomy Journal 83: 870-874.

[5] Keeping, J. H. and Meyer, M. G. (2002). Calcium silicate enhances resistance of sugarcane to the African stalk borer Eldana saccharina Walker (Lepidoptera: Pyralidae). Agric. Forest Enthom. 4: 265-274.

[6] Du Preez, P. (1970). The effect of silica on cane growth. Proc. South Afr. Sugar Tech. Assoc. June 1970. p. 183-188.

[7] Bernal, J. (2008). Response of rice and sugarcane to magnesium silicate in different soils of Colombia, South America. Abstract. In Int. Proc. South Africa. 2008. p. 26.

[8] Toharisman, A., Mulyadi, M., and Rasjid, A. (2010). A new formulated silicon fertilizer for better sugarcane production. Proc. Int. Soc. Sugar Cane Technol. 27: 1-3.

[9] Savant, N. K., Korndörfer, G. H., Datnoff, L. E. and Snyder, G. H. (1999). Silicon nutrition and sugarcane production: a review. Journal of Plant and Nutr., 22: 1853-1903.

[10] Berry, S. D. and Sala, S. (2008). Silicone and plant-parasitic nematodes in sugarcane. Abstract. Int. Proc. South Africa. 2008. p. 27.

[11] Biel, K., Matichenkov, V. and Fomina, I. (2008). Role of silicon in plant defensive system. Abstract. Int. Proc. South Africa. 2008. p. 28.

[12] Ma, J. F. (2004). Role of silicon in enhancing the resistance of plants to biotic and abiotic stresses. Soil Sci Plant Nutr. 50: $11-18$.

[13] Kosobryukhov, A, Shabnova, N., Kreslavsky, V. and Matichenkov, V. (2008). Active silicon for increasing salt tolerance in plants. Abstract. Int. Proc. South Africa. 2008. p 56. 
[14] Liang YC, Chen QR, Liu Q, Zhang WH, Ding RX (2003). Exogenous silicon (Si) increases antioxidant enzyme activity and reduces lipid peroxidation in roots of salt-stressed barley (Hordeum vulgare L.). J. Plant Physiol. 160: 1157-1164.

[15] Ali, A., Shahzad, M. A., Basra, S. H., Iqbal, J., Ahmad, M. and Sarwar, M. (2012). Salt stress alleviation in field crops through nutritional supplementation of silicon. Pakistan Journal of Nutrition, 11 (8): 637-655.

[16] BPS. (2017). Statistik tebu Indonesia (Indonesian sugarcane statistics). Publ. No. 05130.1805.

[17] de Villiers, O. H. (1961) Soil rejuvenation with crushed basalt in Mauritius. Int. Sugar. J. 63: 363-364.

[18] Clements, H. F. (1965). The roles of calcium silicate slag in sugar cane growth. Repts. Hawaiian. Sugar Tech. 25: 103-126.

[19] Ayres, A. S. (1966). Calcium silicate slag as a growth stimulant for sugarcane on low-silicon soils. Soil Sci. 101 (3): 216-227.
[20] Alvares, J. and Gasco, G. J. (1979). Calcium silicate slag for sugar cane in Florida. Part II-Economic response. Sugar y Azucar. 74: 32-35.

[21] Anderson, D. L., Jones, D. B., and Snyder, G. H. (1987). Response of a rice-sugarcane rotation to calcium silicate slag on Everglades Histosols. Agron. J. 79: 531-535.

[22] Allorerung, D. (1989). Influence of steel slag application to red/yellow podzolic soils on soil chemical characteristics, nutrient content and uptake, and yield of sugarcane plantations (Saccharum officinarum L.). Bull. P3G. Indonesia. 136: 14-42.

[23] Priyono, J. (2014). Kompilasi hasil uji efektivitas penggunaan pupuk silikat cair pada beberapa jenis komoditi tanaman pangan, hortikultura, dan perkebunan (2012-2014) (unpublished report).

[24] Djajadi, Hidayati, S. N., Syaputra, R., dan Supriyadi. (2016). Pengaruh pemupukan Si cair terhadap produksi dan rendemen tebu. Jurnal Penelitian Tanaman Industri. 22 (4): 176-181. 